\title{
Australian Journal of Teacher Education
}

2018

\section{Inside the Mentors' Experience: Using Poetic Representation to Examine the Tensions of Mentoring Pre-Service Teachers.}

Sharon L. McDonough

Federation University Australia

Follow this and additional works at: https://ro.ecu.edu.au/ajte

Part of the Teacher Education and Professional Development Commons

\section{Recommended Citation}

McDonough, S. L. (2018). Inside the Mentors' Experience: Using Poetic Representation to Examine the Tensions of Mentoring Pre-Service Teachers.. Australian Journal of Teacher Education, 43(10).

http://dx.doi.org/10.14221/ajte.2018v43.n10.6

This Journal Article is posted at Research Online.

https://ro.ecu.edu.au/ajte/vol43/iss10/6 


\title{
Inside the Mentors' Experience: Using Poetic Representation to Examine the Tensions of Mentoring Pre-Service Teachers.
}

\author{
Sharon McDonough \\ Federation University Australia
}

\begin{abstract}
The supervision and mentoring of pre-service teachers during professional experience is complex work that requires a range of skills and capacities. Professional development for this work has traditionally been limited, however, and mentor teachers report experiencing tensions in their work stemming from their roles as both supporter and assessor of pre-service teachers. Despite the central role that mentors play in professional experience, their voices are underrepresented in the literature. In this paper, I draw on interview data to examine teachers' experiences as mentors and the tensions they experience. I use poetic representation to illuminate the tensions and emotions of mentoring and present seven poems that provide insight into these tensions. I argue that poetic representation of interview data provides an opportunity to connect with the experience of being a mentor and offer suggestions for teacher educators to work collaboratively with mentor teachers to explore the dimensions of their role.
\end{abstract}

Keywords: mentoring; supervision; tensions; pre-service teacher education; poetic representation

\section{Introduction}

The role of professional experience is a central element of initial teacher education programs with school based mentor teachers given the responsibility of supporting preservice teachers as they develop their understandings of teaching (Ambrosetti, 2014). Despite the central role that mentor teachers play in supporting pre-service teachers and the body of literature examining their role, the voices of mentor teachers are underrepresented in the literature (Radford, Howells, \& Williamson, 2018), and in this paper I highlight their voices through the use of poetic representation. Current government initiatives and agendas, both nationally and internationally, focus on developing stronger links between schools and universities with the report of the Teacher Education Ministerial Advisory Group [TEMAG] (2014) in Australia contending that "All academic teacher education should be integrated with practice in schools so that initial teacher education becomes a fused and mutually reinforcing experience of higher education and professional learning" (p. xii). This focus on professional experience is predicated on the notion that teachers in schools have the skills and capacities to mentor pre-service teachers, with the TEMAG (2014) report stating that "school leaders and school sectors have a clear responsibility to select highly effective teachers to supervise pre-service teachers during professional experience" (p. 26). The advisory group also argued that "supervising teachers should have the training and skills required to effectively supervise and assess professional experience placements" (TEMAG, 2014, p. 
xviii). Previous research suggests, however, that professional development for school based mentors is limited and that teachers experience dilemmas that arise from having dual roles as both supporter and judge of pre-service teachers (Bradbury \& Kolballa Jr, 2008; Kwan \& Lopez-Real, 2006). In this paper, I use poetic representation to examine the question "What tensions do mentor teachers experience in their work with pre-service teachers?"

\section{Terminology and Context}

In this paper I focus on initial teacher education in Australia, with this term referring to programs that qualify students to become teachers. Students enrolled in these programs are referred to as pre-service teachers and I have used this term to describe them in the paper. I have used the term professional experience to describe the periods of teaching time that preservice teachers undertake in schools, although I acknowledge that some use the term practicum in the literature in order to describe this experience. The context of professional experience varies across initial teacher education programs and experiences, but generally involves pre-service teachers undertaking teaching for a designated number of days/ weeks while working under the guidance of an experienced school based mentor teacher.

The term for the teachers who support pre-service teachers in school classrooms varies widely in the literature and the variety of terms reflect different time periods and conceptualisations of their role. Le Cornu (2015) identified that these terms include "supervising teachers, mentor teachers, associate teachers, co-operating teachers and school based teacher educators" (p. 3). Ambrosetti and Dekkers (2010) contended that the use of the term 'mentoring' became more pervasive in teacher education in recent years and that despite the use of the term mentor, teachers "engage in both mentoring and supervisory roles" ( $p$. 44). Despite the use of the term supervising teacher being used in the TEMAG (2014) report and by the Australian Institute for Teaching and School Leadership (AITSL), for the purposes of this paper the term mentor teacher has been used to describe the work of those teachers mentoring pre-service teachers in schools as it reflects the term the teachers participating in this study were familiar with and used to describe themselves. The term also relates to the dual role identified by Ambrosetti and Dekkers (2010), and the tensions associated with this dual role are explored in this paper.

\section{Background: Mentoring in Professional Experience}

The work of mentor teachers has been widely considered in the literature (see for example; Ambrosetti, 2014; Ambrosetti \& Dekkers, 2010; Bradbury \& Koballa Jr., 2008; Hall, Draper, Smith \& Bullough Jr., 2008; Hawkey, 2006; Hudson, 2010, 2013, 2016; Leshem, 2014; Walkington, 2005), with a range of literature examining the way mentor teachers understand their role and responsibilities. It is recognised in previous literature that the process of mentoring a pre-service teacher can have benefits for both mentors and mentees, with Hudson (2013) arguing that mentoring functions as professional development. Smith and Nadelson (2016) identified that the process of mentoring prompts teachers to be more reflective about their practice, while Ambrosetti (2014) reported benefits for mentor teachers as including a renewed enthusiasm for teaching and the opportunity to make a difference within their profession.

Despite the identified benefits that can arise from mentoring, there are a number of challenges for mentor teachers who undertake this work. While the TEMAG (2014) report argued that, "International benchmarking of best practice has identified that staff leading and 
supervising professional experience in schools should be exemplary teachers who have undertaken focused training for their roles" (p. 26), research suggests that few mentor teachers receive specific professional development or training prior to commencing their work with pre-service teachers (Ambrosetti, 2014). Lesham (2014) argued that there is no consensus on what constitutes mentoring and suggested that it should be recognised as a "professional role with appropriate PD workshops and time allocation" (p. 269). While the TEMAG (2014) report advocated for mentors who are 'exemplary' teachers, the demand for professional experience continues to grow in an Australian context with "up to 25,000 professional experience placements" (p. 25) needed in the state of Victoria alone. This demand for professional experience opportunities can lead to situations such as those that Ambrosetti (2014) described when she argued that, "In many instances, it is assumed that if a teacher is considered to be an effective practitioner, they can pass on their skills and knowledge to another as a mentor" (p. 30). This assumption that effective classroom teachers automatically make good mentors is misguided (Bradbury \& Koballa Jr., 2008), and neglects the diverse range of skills and capacities that are required by effective mentors. Le Cornu (2015) outlined the elements that characterise high quality supervisory and mentor practices, arguing that when teachers agree to work with a pre-service teacher they "immediately adopt a second role, that of teacher educator" (p. 14). This dual role has been recognised as leading to tensions for mentor teachers and for their practice.

\section{Tensions in Mentoring}

While the concept of mentoring might suggest a more reciprocal relationship than that of supervision, Ambrosetti and Dekkers (2014) contended that a difficulty arises as definitions of what mentoring constitutes do not align with the circumstances and contexts in which the term is used. Ambrosetti (2014) argued that a supervisory approach is associated with assessment and is more likely to "produce graduate teachers who are replicas of the context" (p. 31), while mentoring "concerns the development of the relationship between the mentor and mentee, which in turn provides the underpinning for the growth of the mentee's skills" (p. 31). She acknowledged, however, that in the practice of initial teacher education "mentor teachers need to draw on both mentoring and supervisory skills to perform their role" (Ambrosetti, 2014, p. 32). It is this hybrid role of teacher educator, classroom teacher, mentor, support and judge that can lead to tensions for teachers as they work with pre-service teachers during professional experience.

In considering the tensions that mentor teachers experience, I have drawn from the work of Berry (2007) who described tensions as "feelings of inner turmoil" (p. 119). Berry (2007) argued that the concept of tensions offers a way of examining the feelings and turmoil teacher educators experience as "they found themselves pulled in different directions by competing pedagogical demands in their work and the difficulties they experienced as they learnt to recognise and manage these demands" (p. 120). The recognition of tensions is valuable within the field of mentoring, as while the tensions may not be resolved, their identification and analysis can lead to a deeper understanding of the complex and sophisticated nature of mentoring. As Le Cornu (2015) acknowledged, mentor teachers adopt a dual role as a teacher educator when working with pre-service teachers, making Berry's (2007) notion of tensions one that can be applied in order to highlight the complexity of their work. The dual role mentor teachers hold as both supporter and assessor is likely to lead to competing pedagogical demands as outlined by Berry (2007) and is worthy of examination and articulation. 
Bradbury and Koballa Jr. (2008) argued that the tensions experienced in mentoring pre-service teachers are underrepresented in the literature and contended that the diverse conceptualisations of mentoring held by both mentor teachers and pre-service teachers can contribute to misunderstandings. They argued that the dual role of being both supporter and evaluator is a "dichotomy of roles" that "can put mentors and student teachers in a confusing and untenable position" (Bradbury \& Koballa Jr, 2008, p. 213). The role of having to act as a critical friend who provides feedback and evaluation is recognised as causing dilemmas for a mentor teacher who does "not want to hurt the feelings of the student teacher, but on the other hand, knows how important it is to make the student teacher aware of his/ her weaknesses" (Kwan \& Lopez-Real, 2005, p. 283). Providing feedback that might jeopardise the relationship is seen as a barrier to honest communication (Bradbury \& Koballa Jr., 2008), despite recognition that a key practice of highly effective mentor teachers is the provision of feedback on effectiveness in the classroom (Le Cornu, 2015).

Another tension for mentors recognised in the literature is their own confidence at carrying out the role. Berry (2007) identified that teacher educators could experience a tension between confidence and uncertainty as they moved from "the confidence of established approaches to teaching to explore new, more uncertain approaches" (p. 121). This move from being a confident classroom teacher to a mentor of pre-service teachers is also examined in the literature with Simpson, Hastings and Hill (2007) arguing that teachers want to "get it "right"" (p. 495). They contended that teachers experience a sense of scrutiny as they are required to make their practice public to others, including the pre-service teachers. This sense of uncertainty is also recognised by Hall et al. (2008) who argued that mentor teachers experience feelings of "vulnerability" and lack of confidence in what is an "evershifting, demanding, new professional role" (p. 330). Hawkey's (2006) review of the literature contended that increased scrutiny and accountability in schools leads mentor teachers to feel "responsible" (p. 142) for the outcomes of pre-service teachers. She argued that in this context the "stakes are raised" (Hawkey, 2006, p. 142) and the emotional dimensions of the mentoring relationship can be compounded. Despite acknowledgement in the literature of these tensions, I agree with Hawkey (2006) who argued that little elaboration is given to the emotional aspects of these tensions and mentoring. In this paper, I have sought to illustrate the emotional dimension of the tensions mentor teachers experience by drawing on poetic representation.

\section{Why Poetic Representation?}

Richardson (1997) argued that "lived experience is lived in a body, and poetic representation can touch us where we live, in our bodies" (p. 143). In examining the experience of mentors and the tensions they encounter in their work, poetic representation of data provides an entry point to the visceral, emotional, felt, lived experience and nature of their work. Carroll, Dew and Howden-Chapman (2011) contended that "Poetry captures the essence of the how, the why, the what" (p. 624) and in this paper I have sought to capture the how, why and what of being a mentor teacher. While I have selected the term poetic representation in relation to this work, Prendergast (2009) contended that a variety of terms are used to describe this arts-based practice such as: poetic inquiry; research poetry; data poems; and poetic narrative. Poetic representation is situated within a postmodernist perspective, with Richardson (1997) arguing that postmodernism enables a broadening of what "constitutes social theory, who can do it, and how it might be represented" (p. 123). Görlich (2016) argued that the use of poetic inquiry enables the "broadening of understanding, affective response and representation of the essence of experience" (p. 523) 
and that the postmodern nature of poetic representation enables a dialogue between the "research participant and the reader" (p. 523). In drawing on poetic representation in this paper, I invite readers into a dialogical relationship with the mentor teachers by constructing poems that act as what Furman (2007) described as an "emotional microchip" (p. 1) and which according to Görlich (2016) makes "the emotional context visible" (p. 523). In this way, I have sought to highlight the emotional dimension of the tensions that mentor teachers' experience, something that has been referred to but not considered in depth in the literature. If, as described by Berry (2007), tensions are 'inner turmoil' then poetic representation offers possibilities to connect with the inner turmoil of mentor teachers by creating an evocative representation of the analysed data.

\section{The Ethics of Poetic Representation}

In arguing for the use of poetic representation and the benefits it offers in representing experience, I, like Cahnmann-Taylor (2009), acknowledge that "poetry is a risky business" (p. 16). Like any form of qualitative data analysis, however, the process of constructing poetic representations involves "sifting through data" to identify words, phrases and extracts that "synthesize meaning" (Prendergast, 2009, p. xxiii). The process by which I have constructed the poems from the data needs to be clearly articulated and justified in order to demonstrate the methodological rigour of the approach and this is something I have discussed in the following section of the paper. Choosing poetic representation of data, however, is not just a matter of considering elements that we might consider to be methodological rigour. One of the other considerations I have made in drawing on poetic representation is in relation to the ethics of research representation, something Pickering and Kara (2017) argued is rarely discussed in research. They described an ethics of engagement where ethics is "located in a commitment to actively engage with others through representational acts" (Pickering \& Kara, 2017, p. 1). They contended that creative responses to the representation of data can be an "unsettling of the primacy of representation as 'literal'" (Pickering \& Kara, 2017, p. 1) and argued that choices of how to represent data are connected with concepts of intended audience. Pickering and Kara (2017) identified the way that a move to creative modes of representation might lead to audiences being engaged in emotional, embodied ways rather than through intellectual, cognitive engagement alone, and argued that such work raises questions as to how to engage with "people's minds and emotions" (p. 6). In this paper, I deliberately sought to provide an insight into the emotional aspects of mentoring pre-service teachers and to engage the audience in an intellectual, cognitive and emotional understanding of these aspects. My own epistemological and ethical positionings lead me to argue that there are benefits if we can gain a deeper insight into the emotional aspects of practice and the ways they intersect with cognitive ways of knowing and understanding the work of mentors. I contend that poetic representation provides a vehicle through which to do this.

\section{Method}

In this paper I have drawn on a qualitative study that sought to identify the tensions mentor teachers experienced in their work with pre-service teachers. As a small-scale project, the data has been collected from five teachers who held roles as mentor teachers for preservice teachers. As a small study the findings of this work are not intended to be generalisable, but rather, to provide an insight into the particularity of experience for these teachers in one school context, while also providing an illustration of the ways poetic 
representation might be used to present research findings. All teachers worked in the same school context and were secondary teachers from a variety of discipline areas. There were two males and three females interviewed as part of the project with three teachers having had experience teaching overseas. Table One provides an indication of their teaching and mentoring experience.

\begin{tabular}{|l|l|l|}
\hline $\begin{array}{l}\text { Name of teacher (pseudonyms } \\
\text { have been used) }\end{array}$ & $\begin{array}{l}\text { Number of years teaching } \\
\text { experience }\end{array}$ & $\begin{array}{l}\text { Number of pre-service teachers } \\
\text { mentored. }\end{array}$ \\
\hline Anna & 35 & $\begin{array}{l}\text { Approx. 35 (1 for every year of } \\
\text { career) }\end{array}$ \\
\hline Deborah & $\mathbf{1 8}$ & $\mathbf{3}$ (in Australia) \\
\hline Alex & 24 & $\mathbf{3}$ \\
\hline Amanda & $\mathbf{5}$ & $\mathbf{1}$ \\
\hline Peter & 21 & $\begin{array}{l}\mathbf{2 0} \text { (including one in the first } \\
\text { year of teaching. }\end{array}$ \\
\hline
\end{tabular}

Table 1. List of participants and of their teaching and mentoring experience

\section{Data Collection}

Data was collected through semi-structured interviews of approximately one hour in duration. Each interview consisted of three phases: the first phase invited mentors to discuss their understandings of their role as a mentor; the second phase explored the process of mentoring and any tensions they had experienced; and the final phase of the interview asked them about any support they received in their role. Each interview was audio taped and transcribed for accuracy. The project received ethical clearance from the administering university and in an effort to maintain the privacy and anonymity of the participating teachers, references to the specific subject areas in which they teach have been removed from the data.

\section{Analysis: From Transcript to Poetic Representation}

In order to code the data I began by reading all of the transcripts looking for patterns and recurring ideas. I was also using Berry's (2007) notion of tensions as a lens and was recording codes that represented tensions I identified in the data. I then used these codes and patterns to construct categories that represented the tensions that the mentor teachers were experiencing. The tensions were related to: confidence versus uncertainty; and, individual versus collective responsibility.

After coding the data and identifying key tensions I selected extracts from the transcripts that represented the tensions. Once I had extracts from all of the interviews relating to each tension, I copied phrases and sentences that highlighted key elements of the tension and of the lived experience of the mentor teachers. I pasted these into a new document and then began the process of arranging these into a poetic representation. My process for constructing the poems was influenced by the works of Görlich (2016), Poindexter (1998), and Richardson (1997). I did not change words but used the words as they were expressed by participants. I did however, rearrange sentences or repeat phrases for poetic effect. These choices, are not only choices of writing, but ethical choices about how and why to represent the data in this way. In transforming the transcripts into poetic representations, I attempted to convey the emotional nature of the tensions experienced by the mentor teachers while also remaining true to the sentiments they conveyed in the interviews. Edwards (2015) argued that research poems "allow the whole experiences of participants, 
including the emotional response ... to become accessible, and so allow the exploration of complex professional issues" (p. 37). In drawing on poetic representation, it could be argued that the 'literal' representation is lost, however, like Carroll et al. (2011) I wanted to represent the data in a way that enabled the emotional aspects of mentoring to come "alive in the poetry" (p. 629). These poems are what Prendergast (2009) described as participant-voiced poems where the poems are constructed from transcripts and may contain singular or multiple voices within the one poem. In this way the voices of the participants blend together and the anonymity of individual participants is further protected. The concept of protection is also related to an ethical choice about representation, and in the context of this research, I wanted to provide an insight into the mentor teacher experience in ways that might suggest the collective experience for this small group of teachers, rather than for the specific individuals involved.

\section{Seven Poems: The Tensions of Mentoring}

In this section of the paper I have presented seven poems that reflect the tensions experienced by mentor teachers. Carroll et al. (2011) contended that poetry "can be difficult to interpret" (p. 628) and so in this paper I have discussed the insights I have drawn from these poems in relation to the existing body of literature. There are four poems associated with the tension of confidence versus uncertainty, and three poems associated with the tension of individual versus collective responsibility, and I have examined each of these in turn.

\section{Confidence versus Uncertainty You've Got To.}

You've got to

be able to lead

be confident

be a role model

You've got to

be able to find a common ground

stand beside, not above

treat them with respect

You've got to know your content

know yourself

take yourself into the classroom

critique your practice

You've got to

Be honest

Give critical feedback

Support them with strategies

Poly-fill the gaps

You've got to 
Give them the picture

Of what it's like

to be in a teacher's shoes

\section{Insights on "You've got to".}

You've got to highlights the assumptions that mentor teachers bring to their understanding of the role. The range of skills, knowledge and content that teachers describe as part of their role as a mentor align with those identified in the literature (Ambrosetti \& Dekkers, 2010; Hudson, 2013). The mentor teachers were confident in their articulation of the range of skills and capacities required and were able to describe the multiple dimensions of the work, something Anna described as an "ever-increasing role". Brookfield (1995) provided a framework to examine the assumptions people hold about their practice paradigmatic, prescriptive and causal - with prescriptive assumptions those that refer to the way things should be done. In examining the language that teachers used to describe the role of the mentor it is possible to identify a range of prescriptive assumptions at play, something which was signified by participants using the expression "you've got to" as they began their responses. The mentor teachers perceived that they should be able to lead the pre-service teacher and support them with strategies for professional growth, something also reflected by Aderibigbe, Colucci-Gray and Gray (2016) who argued that mentoring involves guidance including demonstrations of practice and induction into school life. The expression "poly-fill the gaps' may suggest a feeling of responsibility that mentor teachers should be able to provide all the strategies pre-service teachers need, reflecting Hawkey's (2006) argument that mentor teachers feel responsible for the success, or otherwise, of pre-service teacher outcomes.

The mentors also perceived that they should be able to form a positive relationship where they can engage in giving critical and constructive feedback. In identifying the types of things that mentor teachers should be able to do, the participant data suggests the emotional and personal dimension of mentoring. There is a relational skill required in forming a relationship in which critiques are able to be shared, and for the mentor there is a personal disposition (McGraw, McDonough, Wines, \& O'Loughlan, 2016) of being open to critiquing and reflecting on one's own practice. While mentor teachers perceived that they should feel confident in their role as mentors, analysis of the interview data indicated that the three less experienced mentor teachers experienced significant moments of uncertainty about their own skill and capacity as mentors. This questioning of their own capacities is presented in the following poem "Who am I to say?"

\section{Who am I to say?}

Who am I to take on this pre-service teacher?

You might think I'm a good teacher

Who really knows how good I am?

You've never been in my class

No-one's been in my class

Who's to say that I can say

who is a good teacher

and 
who isn't?

We all assume we are good teachers

But how do I know I really am?

Are you really sure you want me to do this?

I was second-guessing

whether

I was the best person for the job

Who am I to say how good they are?

\section{Insights on “Who am I to say?”}

While the TEMAG (2014) report identified that mentor teachers should be expert teachers with specific training and skills, the classroom reality of finding professional experience placements for pre-service teachers means that mentor teachers often move into the role while still in their own early careers, and without specific preparation. Two of the participants in the study were given the role of being a mentor teacher in their graduate year of teaching, with one participant reflecting that this was challenging as they were establishing themselves while trying to support the pre-service teacher. Ambrosetti (2014) identified that the classroom teacher who takes on the role as mentor to a pre-service teacher needs to "nurture, advise, guide, encourage and facilitate authentic learning experiences for developmental growth" (p. 30). For three of the mentors in this study, the responsibility of being the mentor teacher expected to undertake this work led them to question their own skill and highlighted their feelings of uncertainty. By questioning "Who am I to say how good they are?" mentor teachers reflected the responsibility of being both the assessor and the supporter of the pre-service teachers, while another mentor expressed that they were "secondguessing" if they were the best person for the job. Their questioning and uncertainty, however, open up a point worthy of consideration, as to how we determine which teachers in school contexts have the requisite skills and capacities for mentoring. One teacher reflected on the assumption that is made that practising teachers are good teachers, who therefore have the ability to mentor pre-service teachers and they question the validity of this claim, something also raised by Bradbury and Koballa (2008) who argued that "success as a classroom teacher does not translate automatically into success as a mentor" (p. 2143). The self-doubt and uncertainty that mentor teachers feel was also accompanied by a perception that someone from the university would notify them if they were not successfully carrying out their role, a concept explored in the following poem.

\section{Surely.}

Surely someone will tell me if I'm not doing this right

I don't know the answer

I didn't know how to tell them.

I didn't know how to handle it.

I don't think I'm judging them correctly.

I don't think I can judge

I don't know what goes on at the university.

I don't know what they know 
I don't know if I'm doing this right.

I don't know if I'm doing this right.

Surely someone will tell me if I'm not;

Surely someone will tell me

If I'm not doing this right; surely someone will tell me

Surely.

\section{Insights on "Surely".}

In similar ways to Who am I to say? uncertainty on behalf of the less experienced mentors was characterised by their use of the expression "I don't know" as they talked about the dilemmas and challenges they faced in their work as mentor teachers. Mentor teachers in this study expressed uncertainty as to how pre-service teachers have been prepared for professional experience, and they perceived that not knowing the structure of initial teacher education programs makes it difficult for them to judge competence and skill as they do not know what concepts, theories and skills pre-service teachers have explored. Walkington (2005) argued that the ability to provide pre-service teachers with constructive feedback and critique is a key attribute required by mentor teachers, however for participants in this study, their ability to give feedback and critique appeared compromised by their uncertainty about what the pre-service teachers should know. This indicates that the mentor teachers want to evaluate the pre-service teachers fairly, and to not judge them negatively for absence of knowledge or skills that they may not have yet been exposed to at university. Their own lack of confidence in their role as a mentor is also an impediment in their ability to provide constructive critique and feedback, with Wallington (2005) also identifying that lack of confidence can stem from uncertainty about the role and a lack of support. For these mentors, there was belief that 'someone' would tell them if they were not doing the role effectively, however, they also acknowledged that there was little contact with university staff, highlighting the need for more support of mentor teachers across the period of the placement, a concept explored in the following poem.

\section{They'll be Alright.}

I hope that I can guide

It's a big responsibility

It's my name

my reputation

the school's reputation

I don't want to be responsible for

Sending another

Useless person

Into the workforce

I'd like to be able to judge

I'd like some measured guidelines

I'd like someone to tell me how

To handle that difficult conversation 
There's a lot of assumptions

They'll be alright

They're with you

They'll be alright

There's no sitting down

What do you feel?

It's about us having a voice.

It's a professional thing to take on

I haven't had the training

I'm going on gut instinct

It's a professional thing to take on

I'd like to be more professional.

\section{Insights on "They'll be alright".}

The highly personal dimension of mentoring is revealed in this poem, where mentor teachers feel a heavy responsibility for the role they are undertaking, yet lack the confidence in their skills to carry out this work. There is an assumption that their role includes acting as gatekeepers for the integrity of the profession, with mentor teachers carrying the responsibility for this work "it's my name, my reputation". The uncertainty mentor teachers feel in "Surely" is also reinforced in "They'll be alright" where mentor teachers feel a lack of support and an assumption that they are prepared and able to carry out the role. The emotional dimension of mentoring is also identified in one participant's desire to talk about what they feel, with this seen as giving them a "voice" in the mentoring relationship, something which may build confidence in their role. The desire from mentor teachers to talk more with university staff as a means of support is also reflected in the work of Allen, Ambrosetti and Turner (2013). While the work of mentor teachers is recognised as critical in the preparation of teachers, their desire for professional learning, rather than relying on "gut instinct" is identified through this poem. Similarly, Hudson (2010) identified that mentor teachers sought more opportunities for professional learning in mentoring in order to develop their skill in the role. The second tension identified in the data was that of individual versus collective responsibility and this tension closely interrelates to the tension around confidence versus uncertainty, however, relates more specifically to those situations and emotions generated by mentor teachers having to carry out the dual role of both supporter and judge.

\section{Individual versus Collective Responsibility The Clash}

I think it's important

Appropriate mentors be given

What I consider appropriate mentors

Is

\section{Not}

What the school administration

Think 
I worry about

the experience they'll get

the judgements they'll make of the school

the judgement they'll make the of the calibre of what they're seeing

Sometimes

The wheels fall off

It's damage control

A camouflage

That worries me

I've

tossed

and

turned

about it

\section{Insights on "The Clash".}

The challenge of identifying appropriate mentors is reflected in "The Clash" with some of the participants identifying the elements of the systems and structures of schools that may see mentor teachers who are not best placed to support novice pre-service teachers. While individual teachers may express concern about who makes appropriate mentor teachers, this is in opposition with a collective understanding in the school. The implications of these decisions impact on individuals as they worry about where the responsibility for this lies. Orland-Barak, Kheir-Farraj and Becher (2013) argued that it is important to "understand how the cultural and political factors of a mentoring context affect the kind of dilemmas that mentors experience in their work" (p. 77). The pressure on schools to cater for the many preservice teachers who require professional experience each year is conveyed in this poem. The poem provides an insight into the dilemma and the stress experienced by a teacher who is concerned about who should be mentor teachers and the impact on the quality of the professional experience. This has important implications for those of us working in teacher education who may also be pressured to find professional experience placements, and who may then exert that pressure on school based colleagues. The integrity of the professional experience and the support both the mentor and the pre-service teachers receive during the experience is worthy of consideration. Are we, as teacher educators, placing schools and mentor teachers under additional emotional stress by asking them to accommodate our preservice teachers? What opportunities do we provide to schools as they seek to support mentor teachers who may be ill-prepared or not suited for the work? This additional stress can then result in situations where "the wheels fall off" and as the mentor teacher identifies, the school and university may move into "damage control", in order to "camouflage" the situation. This raises important questions about how systems might work together to navigate these situations, or to provide greater support in situations that might be hidden from view. In reflecting on the attributes required by mentor teachers to support pre-service teachers, participants described the attributes they perceived as important. Analysis of the responses highlights the tensions inherent in these attributes, as explored in the following poem "Torn". 
Australian Journal of Teacher Education

Torn

I am approachable

I hope I'm not too critical

I'm not too in your face

I'm not set in any ways

I'm quite kind and nice

I could understand

But then

He was a nice kid

I didn't want to say anything bad

I know you should be able to

You want to appear to be

Helpful

and

Open

and

At the same time

How much to give them?

How much to offer?

You are assessing them

I'm supposed to say about this poor,

This poor

Teacher's future

I don't like conflict

I don't like making people feel bad

But

I kept saying

Would I want you in charge of a classroom?

Would I want you teaching; my son? My daughter?

I kept coming back to

The answer was

No.

If I can't say yes.

I can't pass you.

Insights on "Torn".

Hudson's (2010) five factor model of mentoring includes personal attributes and feedback, with the personal attributes displayed by mentor teachers regarded as important in supporting pre-service teachers and in fostering reflection on practice. Personal attributes are also closely connected with the ability to provide feedback to support growth and 
development of the pre-service teacher. In "Torn" mentor teachers reflected on their own personal attributes and demonstrate a willingness to support pre-service teachers. What is demonstrated, however, is their dilemma at having the role of both supporter and judge and the way it impacted on their ability to offer support. Their mixed emotions are present as they described perceiving pre-service teachers as "nice" but having to mediate emotional responses and personal connections, with their role as judge and assessor of progress. As identified above their comments reflected the assumption that they are gatekeepers who have individual and sole responsibility to decide whether or not to pass or fail pre-service teachers. Rorrison (2010) argued that the comment "Would you want this person teaching your children or grandchildren?" is used as the "defining statement around student teacher assessment" (p. 507), and instead contended that a focus on progress rather than the achievement of "arbitrary or context dependent outcomes might provide a better lens for the assessment of student teachers" (p. 508). For the mentor teachers, the responsibility of making judgements about the future of pre-service teachers is one that weighed heavily, and I suggest that it is their uncertainty about the evaluation process and the dilemma they face that led them to using their own personal lens, "would I want you teaching my children?", for evaluation. Their response also suggested a sense of isolation in that they have to make this judgement without support or guidance from university staff, highlighting the tension at not having a sense of collective responsibility for the making and application of judgements about pre-service teacher performance. Their desire for a shared, collective responsibility is demonstrated in the following poem, "Someone".

\section{Someone.}

It's a drive-by

How often do we have pre-service teachers where no-one comes from the institution?

You need a bridge person

\section{Someone}

Who comes

Who visits

Who rings

Who sees if I'm actually doing this right

\section{Someone}

To touch base with

To give a rundown of how they're travelling

To come and watch them teach

To meet with all of us

To set up a small body in the school

Someone

To talk about

Anything that comes up

How people dealt with it

It would be amazing to have 10 mentors who have done it 16 times

Someone

Who can pick 
and

which way to jump

how to jump

The uni is putting this

Responsibility

On us

You want to have

Someone

To share the responsibility

\section{Insights on "Someone".}

This poem highlights the tension of individual versus collective responsibility for supporting pre-service teachers and mentors. In 2005 Walkington argued that "In addition to professionally developing teachers as mentors, the partnership can be strengthened by encouraging and valuing the contribution from school to universities" (p. 34). Despite this, the professional development of mentors remains inconsistent across systems and contexts. Aderibigbe, Colucci-Gray and Gray (2016) contended that while there are moves towards more collaborative models of mentoring power relations exist and that "much needs to be understood about the nature of decision-making processes within an environment of unequal roles and responsibilities" (p. 12). "Someone" represents these power relations and the desire of mentor teachers to have someone share the responsibility they feel in mentoring preservice teachers. Mentor teachers identified communities of professional learning that could be created within schools among those holding a mentor role, and ways that these people could be supported by university staff in order to share a collective responsibility. In identifying the processes that could offer them support as mentors, the participants also identified ways this could support the learning of pre-service teachers through creating a community which has learning at its core. Mentor teachers described the valuable learning that could occur in school contexts if teams of mentors were to come together and share examples of personal practice and the strategies teachers use for navigating challenging situations. They also highlighted the way that engagement with university staff could enable them to develop confidence and understanding in both their role and in what pre-service teachers are expected to be able to do and achieve while on placement.

\section{Concluding Thoughts}

Considering the nature of tensions that mentor teachers experience in their work is valuable, as through articulating and examining these tensions we are able to more effectively map the work mentor teachers undertake and the challenges they face in carrying out their roles. As Berry (2007) argued, examining tensions leads to a greater understanding of the complex work of those working in teacher education and using tensions as a framework has enabled me to explore and highlight the complex nature of mentoring. As pressure for professional experience placements intensifies (TEMAG, 2014) and as schools and universities continue to develop closer relationships for professional experience, this mapping of the work of mentor teachers is important in determining ways to support teachers and build collective and shared understandings of practice. 
The findings of this small scale study have reinforced previous studies in the field of mentoring in initial teacher education which suggest that mentor teachers are ill-prepared for their roles and experience tensions that result from their dual role as both supporter and judge of pre-service teachers (Ambrosetti, 2014; Bradbury \& Koballa Jr., 2008; Le Cornu, 2015). Despite our previous understandings of the challenges mentor teachers can face, the data suggests that a gap still exists between theoretical understandings of ways to support mentors and the practices occurring between schools and universities. Mentor teachers are keen to engage in ongoing professional learning in order to develop their skills as mentor teachers, and the data suggests a desire for closer partnerships with university staff in order to develop a shared, collective understanding and responsibility of the work of mentoring and assessing pre-service teachers. The development of communities of practice among mentors in schools which are supported by university staff may provide an avenue for the sharing of practice, challenges and tensions. These communities of practice have the possibility to be meaningful professional learning experiences for all, particularly for new mentors who are developing their skills and approaches.

Using poetic representation as a way of presenting these tensions exposes the felt, emotional dimension of the tensions, and provides an insight into the way emotions mediate the work that mentor teachers undertake as they work with pre-service teachers. Drawing on poetic representation as a means of displaying and disseminating research data offers scope in enabling the voices, experiences and emotions of mentor teachers to be heard in ways that move beyond cognitive, intellectual modes. In highlighting the emotional, felt experience of mentoring we are also able to generate understandings of how supporting mentors is more than providing a set of skills to be deployed when working with pre-service teachers, but also involves processes for navigating the emotionally challenging and demanding work of mentoring. Failure to pay attention to these emotional aspects of mentoring work places the mentor teacher at risk of bearing individual responsibility for pre-service teacher progress, rather than reinforcing that mentoring is a collective, shared process. The challenge for universities is to find ways to work collaboratively and collectively with mentor teachers to examine all aspects of mentoring practice, including those emotional, embodied experiences and to develop meaningful professional learning that engages all of these elements.

\section{References}

Aderibigbe, S., Colucci-Gray, L., \& Gray, D.S. (2016). Conceptions and expectations of mentoring relationships in a teacher education reform context. Mentoring and Tutoring: Partnership in Learning, 24(1), 8-29. https://doi.org/10.1080/13611267.2016.1163636

Allen, J., Ambrosetti, A., \& Turner, D. (2013). How school and university supervising staff perceive the pre-service teacher education practicum: A comparative study. Australian Journal of Teacher Education, 38(4), 108-128. https://doi.org/10.14221/ajte.2013v38n4.9

Ambrosetti, A. (2014). Are you ready to be a mentor? Preparing teachers for mentoring preservice teachers. Australian Journal of Teacher Education, 39(6), 30-42. https://doi.org/10.14221/ajte.2014v39n6.2

Ambrosetti, A., \& Dekkers, J. (2010). The interconnectedness of the roles of mentors and mentees in pre-service teacher education mentoring relationships. Australian Journal of Teacher Education, 35(6), 42- 55. https://doi.org/10.14221/ajte.2010v35n6.3 
Berry, A. (2007). Reconceptualising teacher educator knowledge as tensions: Exploring the tension between valuing and reconstructing experience. Studying Teacher Education: A journal of self-study of teacher education practices, 3, 117-134. https://doi.org/10.1080/17425960701656510

Bradbury, L.U., \& Koballa Jr, T.R. (2008). Borders to cross: Identifying sources of tension in mentor-intern relationships. Teaching and Teacher Education, 24, 2132-2145. https://doi.org/10.1016/j.tate.2008.03.002

Brookfield, S. (1995). Becoming a critically reflective teacher. San Francisco, USA: JosseyBass.

Cahnmann-Taylor, M. (2009). The craft, practice and possibility of poetry in educational research. In M. Prendergast, C. Leggo, P. Sameshima. (Eds.). Poetic inquiry: Vibrant voices in the social sciences (pp. 13-31). Rotterdam: Sense.

Carroll, P., Dew, P., \& Howden-Chapman, P. (2011). The heart of the matter: Using poetry as a method of ethnographic inquiry to represent and present experiences of the informally housed in Aotearoa/New Zealand. Qualitative Inquiry, 17(7), 623-630. https://doi.org/10.1177/1077800411414003

Edwards, S.L. (2015). Transforming the findings of narrative research into poetry. Nurse Researcher, 22(5), 35-39. https://doi.org/10.7748/nr.22.5.35.e1322

Furman, R. (2007). Poetry and narrative as qualitative data: Explorations into existential theory. The Indo-Pacific Journal of Phenomenology, 7(1), 1-9. https://doi.org/10.1080/20797222.2007.11433939

Görlich, A. (2016). Poetic inquiry: Understanding youth on the margins of education. International Journal of Qualitative Studies in Education, 29(4), 520-535. https://doi.org/10.1080/09518398.2015.1063734

Hall, K.M., Draper, R.J., Smith, L.K., \& Bullough Jr., R.V. (2008). More than a place to teach: Exploring the perceptions of the roles and responsibilities of mentor teachers. Mentoring and Tutoring: Partnership in Learning, 16(3), 328-345. https://doi.org/10.1080/13611260802231708

Hawkey, K. (2006). Emotional intelligence and mentoring in pre-service teacher education: A literature review. Mentoring and Tutoring: Partnership in Learning, 14(2), 137-147. https://doi.org/10.1080/13611260500493485

Hudson, P. (2016). Forming the mentor-mentee relationship. Mentoring and Tutoring: Partnership in Learning, 24(1), 30-43. https://doi.org/10.1080/13611267.2016.1163637

Hudson, P. (2013). Mentoring as professional growth and development: 'Growth for both' mentor and mentee. Professional Development in Education, 39(5), 771-783. https://doi.org/10.1080/19415257.2012.749415

Hudson, P. (2010). Mentors report on their own mentoring practices. Australian Journal of Teacher Education, 35(7), 30-42. https://doi.org/10.14221/ajte.2010v35n7.3

Kwan, T., \& Lopez-Real, F. (2006). Mentors' perceptions of their roles in mentoring student teachers. Asia-Pacific Journal of Teacher Education, 33(3), 275-287. https://doi.org/10.1080/13598660500286267

Le Cornu, R. (2015). Key components of effective professional experience in initial teacher education in Australia: A paper prepared for the Australian Institute for Teaching and School Leadership. Melbourne, Australia: Australian Institute for Teaching and School Leadership.

Lesham, S. (2014). How do teacher mentors perceive their role, does it matter? Asia-Pacific Journal of Teacher Education, 42(3), 261-274. https://doi.org/10.1080/1359866X.2014.896870 
McGraw, A., McDonough, S., Wines, C., \& O’Loughlan, C. (2016). Activating teaching dispositions in carefully constructed contexts: Examining the impact of classroom intensives. In R. Brandenburg, S. McDonough, J. Burke \& S. White (Eds.), Teacher Education: Innovation, Intervention and Impact (pp. 193-210). Singapore: Springer.

Orland-Barak, L., Kheir-Farraj, R., \& Becher, A. (2013). Mentoring in contexts of cultural and political friction: Moral dilemmas of mentors and their management in practice. Mentoring and Tutoring: Partnership in Learning, 21(1), 76-95.

Pickering, L., \& Kara, H. (2017). Presenting and representing others: Towards an ethics of engagement. International Journal of Social Research Methodology, https://doi.org/10.1080/13645579.2017.1287875

Poindexter, C.C. (1998). Poetry as data analysis: Honoring the words of research participants. Reflections: Narratives of Professional Helping, Summer, 22-25.

Prendergast, M. (2009). The phenomena of poetry in research: "Poem is what?" Poetic Inquiry in Qualitative Social Science Research. In M. Prendergast, C. Leggo, P. Sameshima. (Eds.). Poetic inquiry: Vibrant voices in the social sciences (pp. xix-3). Rotterdam: Sense.

Radford, R., Howells, K., \& Williamson, J. (2018). Listening to mentor teachers' voices in uncertain times. In D. Heck \& A. Ambrosetti. (Eds.). Teacher Education in and for uncertain times (pp. 67-82). Singapore: Springer. https://doi.org/10.1007/978-981-10$\underline{8648-9 \_5}$

Richardson, L. (1997). Fields of play: Constructing an academic life. New Jersey, USA: Rutgers University Press.

Rorrison, D. (2010). Assessment of the practicum in teacher education: Advocating for the student teacher and questioning the gatekeepers. Educational Studies, 36(5), December, 505-519. https://doi.org/10.1080/03055691003729013

Simpson, T., Hastings, W., \& Hill, B. (2007). "I knew that she was watching me": The professional benefits of mentoring. Teachers and Teaching: Theory and Practice, 13(5), 481-498. https://doi.org/10.1080/13540600701561695

Smith, J., \& Nadelson, L. (2016). Learning for you and learning for me: Mentoring as professional development for mentor teachers. Mentoring and Tutoring: Partnership in Learning, 24(1), 59-72. https://doi.org/10.1080/13611267.2016.1165489

Teacher Education Ministerial Advisory Group (TEMAG). (2014). Action now: Classroom ready teachers. Retrieved from: https://docs.education.gov.au/system/files/doc/other/action_now_classroom_ready_te achers_accessible.pdf

Walkington, J. (2005). Mentoring pre-service teachers in the preschool setting: Perceptions of the role. Australian Journal of Early Childhood, 30(1), 28-35. 